\title{
Az emlékezet mint konstrukció és hagyomány
}

\author{
(Weöres Sándor, Tóth Krisztina) ${ }^{1}$
}

\begin{abstract}
„Annyi bizonyos, hogy fiatalkoromban többet írtam az öregségről, mint a fiatalságról, szerelemről. Ami az emberben kezdettől fogva megvan, újra és újra kifejeződik. A régi formák, régi hangulatok újraélednek. A témák köröznek az emberben." (A feledésre..., 1993, 119. o.)
\end{abstract}

„Úgy érzem, törekvéseim felfüzhetőek egyetlen domináns szálra, a motívumok, az intonáció mind egy irányba tartanak. A Porhó válogatását is ezzel a céllal készítettem: szerettem volna a magam számára is tisztázni, hol vannak ezek az erővonalak. Tudtam, hogy az embert mindig ugyanaz foglalkoztatja, csak másképp: újabb és újabb képeket, más helyzeteket tesz meg hordozónak, ám az érzelmi-indulati háttér nem változik.” (Lackfi, 2003, 88. o.)

,[...] költőnek lenni nem egyéb, mint tudatosan fenntartani a problematikusság gyötrelmes állapotát. Hol végződik az ars, és hol kezdődik a poetica? [...] A posztmodern rétorai megkíséreltek választ adni erre. Ám miféle helymegjelölés az, hogy valami utáninak nyilvánítjuk magunkat, mielőtt definiáltuk volna azt a valamit, aminek állítólag utána vagyunk? Szerintem azok, akik ilyen módon próbálják helyüket keresni a világban, az igazán lényeges kérdést nem tudták megválaszolni, hogy tudniillik kicsodák is ők maguk. József Attila naiv megalomániája megmosolyogtató, de rendszeralkotó igyekezete még mindig tiszteletre és szeretetre méltóbb, mint az öntudatos semmit mondás, mint a filozófiává felmagasztosított impotencia.” (Petri, 2007, 142. o.)

\section{Emlékezet, filozófia, poétika. A Weöres-recepció néhány tanulsága}

$\mathrm{H}$ a a Weöres Sándor-életmü iránt érdeklődő olvasó a szerzőt körülvevő kritikai szövegmezöt is áttekinti, könnyen jut arra a megállapításra, hogy az emlékezet szerveződésére irányuló kérdések utóbbiban korlátozottan bukkannak fel. Eme jelenség oka azonban nem feltétlenül a különböző receptív stratégiák értelmezői közösségeinek mulasztásában jelölhető meg: egyrészt metodikai eredetű, másrészt magából az anyagból következik. Az 1970-es és az 1980-as évek esztétizáló értelmezői gyakorlatának müködtetői ugyanis nem, vagy csak nagyon érintőlegesen tárgyalják, hogy a weöresi többszólamúság - melynek egyaránt összetevője a szerepjátszó hajlam, a különbözö zenei formák imitációja, a líranyelvi személytelenség, a hagyomány- és irodalomtörténet problematikus müködésmódját prezentáló szövegmező, a filozófiai diskurzusrend versnyelvbe való integrál(ód)ása, a ritmus jelentésképző szerepének hangsúlyos deklarálása - miként függ össze az egyes textusokban a magyar nyelv történetiségével, annak szemantizálásban való aktív szerepével, valamint a nyelvi tradícióból következő értelmi megelőzöttséggel. Mivel a primer, illetve a küldetéses, képviseleti líraeszményből kinö- 
vő és Weöres humanista voltát bizonygató olvasatok egy, a mitikus kort tematizáló paradigma felől jól megtámogathatóak ${ }^{2}$, az aranykori, Hamvas Béla-i hagyományból következő idő- és emlékezet-felfogás majdnem minden korabeli interpretatív megnyilvánulásban dominánsnak mondható, s szinte fel sem merül az emlékezet/emlékezés nyelvi természete. Másképpen: miközben a referenciális olvasatok közzétevői jórészt eltekintenek a fent említett relációhálótól és észrevételeiket többnyire a moralitás és az etikum mentén fogalmazzák meg, olyan gyakorlatot tesznek általánossá, amely figyelmen kívül hagyja a költészet anyagának speciális jellegét, annak egyik alapvető poétikai összetevőjét és a szöveg mindenkori apellatív funkcióját:

„Itt van egy menthetetlen és áthidalhatatlan szakadék, hogy aki a verset olvassa az valamit olvas. Témát olvas, problematikát, ami az övé. Aki a verset írja, az á-t meg í-t, ó-t ír, és teljesen közömbös számára, hogy mint életbeli problematika az a vers mit jelent." (A költészet..., 1993, 216. o.)

„-- Mi ingerel téged arra, hogy éppen amit megírsz, azt írd meg?

- Hát éppen ami foglalkoztat. Ritka esetben a téma vagy a gondolat, sokkal gyakrabban egy fakturális lehetőség, egy formai vagy hangzási esetlegesség, vagy speciálisan recsegö részhangzás [...]”. (Írószobám..., 1993, 273. o.)

„[...] a költészetben a józanság és értelem más, mint, mondjuk, a piacon: a költőnek újra meg újra át kell törni a már megszokott és elfogadott eszmei, nyelvi, szerkezeti formákat, hol az egyszerübb, hol a bonyolultabb felé, hogy olyat adhasson embertársainak, ami még nincs birtokukban. Aki ezt a művésztől zokon veszi, rákiálthat az ércek és források kutatójára is: nem arra van az épített út." (Weöres, 1993, 42. o.)

A fenti idézetekből jól látszik, hogy Weöres igyekezett elválasztani a lírát mint olyat a témára koncentráló befogadói attitüdtől, valamint a racionalitástól ${ }^{3}$, s visszavezetni azt saját elemi egységeihez, vagyis a hangokhoz, illetve az azokból következö ritmushoz.

A két bemutatott gondolatrendszer, azaz a kritika döntően referenciális értelmezői gyakorlata és a költői poétika közötti különbség abból (is) adódott, hogy Weöres a versnyelvi megnyilatkozásról tett megjegyzéseit sem teoretikusan, például $A$ vers születésében, sem leveleiben, esszéiben, könyvbírálataiban, interjúiban nem kapcsolta össze az emlékezet/ emlékezés kérdéskörével. Ha egyáltalán szóba hozta az utóbbi problémát ${ }^{4}$, azt mindannyiszor valamiféle transzcendens ösállapot, az eredendő teljesség ${ }^{5}$ irányából tette meg (sokszor verseiben is) ${ }^{6}$, amelyektől az emberi történelem ${ }^{7}$ és az ahhoz rendelhető tér-idő élesen eltér:

„Szerintem alapvető dolog, hogy az ember önmagában a gyermekkori, sőt csecsemőkori vagy akár magzati vagy fogantatás előtti lényét megörizhesse. Az evidencia szó is körülbelül ezt jelenti: masszív lényeget.” (Negyvenhat perc..., 1993, 39. o.)

„[...] a történelmen cakkpakk most már túl kell lépni! Át kell menni egy történelem utáni korszakba, addig béke és nyugalom nem lesz, sőt. Atomfegyver és hasonlók birtokában az ember előbb-utóbb kifüstöli lába alól a talajt, még mielőtt elérhetné a történelem utáni kor felnőttségét és békéjét." (Válaszolni..., 1993, 351. o.)

„Az én időélményem, amit még egyetlen írásomban se tudtam még csak érzékeltetni sem, az, hogy tulajdonképpen az idő áll, és tömbszerü és végtelen, nem gondoltam, hogy a jövő és a múlt is benne van, hanem csak úgy, hogy jelen van. Mióta 
a mindenség létezik, elkezdődött a jelen, és azt sosem érte utol a múlt, és sosincs reményünk arra, hogy a jövőt megközelítsük. Szóval az idő a jelennek egy végtelen tömbje, amin belül a lények megjelennek, mozognak, kihalnak belöle, de sose volt múlt és sose lesz jövő." (A vers..., 1993, 62. o.)

Mindez kiváló alapot szolgáltatott arra, hogy Weöres ösköltőként ${ }^{8}$, „az abszolút örök emlékezet" megtestesítőjeként (Bertha, 1990, 549. o.) aposztrofálódjék. Különösen szimptomatikus Bata Imre véleménye, aki, miután az alinearitás és linearitás fogalomkettőse, valamint az időszerkezet eltérései mentén következetesen elhatárolja egymástól a költői és a mindennapi emlékezetet, a $F u ̈$, $f a$, füst kapcsán a következő kijelentéseket teszi:

„Babits szerint a költőnek »elődi emlékezete« van. Weöresben ez támaszt olyan fölismerést, hogy mintha lett volna már. Ebben van az inkarnáció személyes élményi háttere nála, s innen ered az a meggyőződés is, hogy a költő médium. A lélek archaikus rétegeit borzolja ez az emlékezőképesség; a költő az anyaméh csöndjére is emlékezni vél, az éntudat előtti állapotra lát, álomvilágra, tagolatlan egységre, melynek eredetét a költő maga sem tudja." (Bata, 1979, 19. o.)

„Az ösvilágokat kereste a térben is. Müvelődése is ilyen irányba vonzotta. Az ősvilágokat kereste az időben is. Az aranykort, a mítoszt. [...] Az eltünt és ígéretes aranykort akarja felidézni ellensúlyképpen a világ szörnyeteg démoniságával szemben. [...] kilépni az egyetlen élet teréből és idejéből. Ilyen lesz majd a vers [...] Weöres kezén." (Bata, 1979, 33. o. $)^{9}$

Az ehhez hasonló idézeteket hosszasan lehetne még sorolni, ám ennyiből is kitünik, a kortárs kritika Weöresben elsősorban a mitikus emlékezet tematizálóját látta. Mivel a transzcendens valóság az ember számára szinte menthetetlenül elveszett ${ }^{10}$, a költő, Hamvasnál hovatovább a költészet számára nem maradt más hátra, mint az előbbi felidézése, átesztétizált (vissza)realizálása. ${ }^{11}$ Amikor az életmü humánus vagy ahumánus volta körüli vita 1947-ben kipattan, a tárgyalt lírikus emberszeretete, társadalom- és történelemismerete, -felfogása is részben innen nyeri már-már elkeseredett ${ }^{12}$ igazolását:

„Ahogy első pillanatra meglepőnek látszik (persze csak korcs irodalmi ember számára), hogy az, akinek verseiben tilinkóként fújdossák a haranglábakat, épp az egy pozitív magyar realizmus egyik legjobb költöje legyen [...]: éppolyan meglepetés lehet, hogy a tülyukakban ujjlenyomatokat nyalogató Weöres [...] egyike a legmélyebb moralistáknak és bölcseknek, nagyszerü szeme van a társadalombírálathoz, szenvedélyes híve a legnagyobb jóságnak és az érzelgésen messzi túli kozmikus szeretetnek. Ez is rikító bizonyítéka, hogy attól, hogy az ember gurigázó szójátékokkal hancúrozik: még nagy szent, reformer vagy humanista történész is lehet." (Szentkuthy, 1990, 264-265. o.)

Természetesen nem azt akarom mondani, hogy a fentiekben részletezett interpretatív vonulatnak nincsen legitimációja, csupán azt, hogy az emlékezet szerveződése, diszkurzív, nyelvi aktushoz kötött volta a Weöres-szakirodalomban csak nagyon halványan, áttételesen van jelen. Pedig - egy pillanatra még Bata Imre alapos munkájánál maradva - a kritikai irodalomban szembetünően jó kiindulási pontok is találhatóak az emlékezet konstrukció-jellegének bizonyításához. ${ }^{13}$ Az iménti szerző egyik sarkalatos megállapítása szerint a költői memóriamüködés olyan relációhálót alkot, amely az eseményeket a saját belső rendjének megfelelően viszi színre, s ez az immanens rend - eltérően a 
köznapi emlékezettől - alineáris (Bata, 1979, 14. o.). Mindezen túl arról sem szabad megfeledkezni, figyelmeztet Bata, hogy a költemény nyelviesülése során a széttartó eseményekből $1^{14}$ - a vershez eredendően hozzátartozó ritmus közegében - új, a jelenben nem tapasztalt világismeret születik. ${ }^{15}$ Gondolatmenete az emlékezet távol-keleti filozófiai vonatkozásának argumentálásakor ${ }^{16}$, annak ősvilághoz való kapcsolásakor szakad el a konstrukcióval történő összeegyeztethetőségtől. A transzcendens valóság ugyanis - ahogy Hamvas írja - van. Nem lehet, és nem is kell újrateremteni, csupán belehelyezkedni. ${ }^{17}$

Az eddigiek során vázolt ellentmondás vezérfonalként húzódik végig a Weöres-befogadás tradícióján. Az alábbiakban következő elemzés(ek) tétje éppen ezért az, miképp lehet az emlékezet szerveződését a ritmussal, a hangzóssággal és a szó által hordozott történeti jelentéssel összefüggésbe hozni, e relációháló milyen viszonyban áll a versek keleti filozófiai hátterével, s mindennek milyen hagyománytörténeti következményei vannak. A Tóth Krisztina-életmüben több olyan textus is fellelhetö, amely a Weöres-korpusz különböző szövegeire reflektál, s ezek elemzése mindeddig csak részleteiben történt meg: bár a kortárs költő kiválasztása motiválatlannak tünik, poétikai nézőpontból - mint azt majd bizonyítani igyekszem - jól indokolható.

\section{A megnevezés tétele, a tétel megnevezése: $F u ̈, f a$, füst}

Mikor az irodalomtörténet-írás a Weöres Sándor-életmü egyik legközismertebb, ugyanakkor talán a legszerteágazóbb humántudományi irányokból megközelített sajátosságával, azaz keleti filozófiai diskurzusokba való beágyazottságával szembesül, mindannyiszor elbizonytalanodni látszik. ${ }^{18}$ Ám a keleti filozófiai diskurzusokat magába olvasztó weöresi líranyelv esetében a mai napig tapasztalható értelmezői tanácstalanság nem abból adódik, hogy a kritika a korpusz egyik legmeghatározóbb markerét figyelmen kívül hagyná, hanem sokkal inkább abból, hogy törekvéseit ennek ellenére egyfajta rekonstruktív szándék mentén jelöli ki. ${ }^{19}$ Habár az irodalmi müalkotás véleményem szerint sohasem tekinthető egy-egy filozófiai tétel, diskurzus illusztrációjának, előbbiek jelentéssürítő és -generáló volta tagadhatatlan. Számomra azonban az is bizonyos, hogy a filozófia mint kiindulópont és a konstituálódó versszöveg szemantikuma között - ahogy arra Kabdebó Lóránt is figyelmeztet ${ }^{20}$ - feszültség keletkezik, amely összefügg a nyelv írásaktusban megnyilvánuló társalkotó szerepével. Ráadásul a filozófiai háttér a csöngei költő nem egy versében az emlékezetbe, valamint az emlékezésbe ágyazódik, s ez a tény tovább bonyolítja az amúgy sem könnyü helyzetben lévő olvasó dolgát.

Weöres Fü, fa füst címü szövege nemcsak azért különösen figyelemre méltó, mert keletkezéstörténetét magától a költőtől ismerjük ${ }^{21}$, hanem azért is, mert a vers 1937-es datálása jól láthatóvá teszi a bevezetőben említett anomáliák Weöres-lírában bekövetkező igen korai realizálódását. Mindezen túl pedig olyan problémát érint, amely mind a keleti filozófiai rendszerekben, mind a nyugati nyelvelméletben és - utóbbin keresztül - ontológiában meghatározó erejünek mondható.

A racionális gondolkodás mint a teljes lét kibontakozását gúzsba kötő kategorizáló megértésmód kérdésköre valószínüleg minden távol-keleti filozófiai irányzatban fellelhető. Lie- $c i^{22}$-reinterpretációjában A. C. Graham $(1995,12$. o.) a következőképpen fejti ki az elgondolás lényegét:

„Az Ég és a Föld tervek és célok nélkül tevékenykedik, a ce-jant ${ }^{23}$ követve. Az ember is hasonló utat jár be, a növekedésen és a pusztuláson keresztül, anélkül, hogy a születést vagy a halált választaná. A számtalan dolog közül ugyanakkor mégis megpróbálja cselekedeteit a gondolkodásra és a tudásra alapozni, morális és 
gyakorlati vezérelvet alkot, hogy különválassza a jó és a rossz cselekedeteket egymástól. Ha vissza akar térni az Útra, akkor meg kell szabadulnia addigi tudásától, fel kell hagynia azzal, hogy állandóan kategorizálja a dolgokat, s hogy állandóan érvényesítse az akaratát, vissza kell állítania az újszülött spontaneitását.”

A hinduizmus a fent említett racionalizáló/kategorizáló gondolkodásmódot hovatovább a jellel, ezáltal magával a nyelvvel és a szóval hozza összefüggésbe, vagyis elvitatja a nyelv használójától a megnevezés általi megismerés lehetőségét. ${ }^{24}$ Így a hindu világnézet - a fenti megállapításból is következően - az egész megnyilvánult mindenséget és annak minden jelenségét a 'náma-rúpa' ('név és forma') kifejezéssel írja körül (Baktay, é. n., 116. o.): mivel az értelem képtelen felfogni a név és forma nélküli dolgokat - áll a védikus hagyományban -, Mája objektív valóságot egyszerre eltakaró és sejtető fátyla tulajdonképpen minden nyelvhasználati aktust követően újraszövődik. A jel (szó) adekvát megismerést ellehetetlenítő természete a buddhista filozófiában sem ismeretlen gondolat: a Gyémánt szútra ${ }^{25}$ szerzetese egyenesen a megnevezés kényszerétől mentes létért fohászkodik: ${ }^{26},[\ldots]$ a bódhiszattva, a nagyszerü lény úgy adjon ajándékot, hogy nem bízik semmiféle jel képzetében" (Gyémánt..., 1998, 11. o.).

Weöres Sándor Fü, fa füst címü verse gond nélkül olvasható a fenti filozófiai tradíció irányából. A szöveg narratív elemeket is magába olvasztó íve egy olyan folyamatot ír le, amelynek során az alany az objektív világot kategorizáló és az ősegységet megbontó nyelvet fokról-fokra elsajátítja. A váltás tematizálása a negyedik és az ötödik versszakban a legerősebb. A két strófa szinte az összes előző bekezdésben felemlegetett kulcsfogalmat (ős-egység, ész, név stb.) színre viszi:

Fogatlan szájjal tátogattam és érzés nélkül jött sírás-nevetés, a sorsom nem volt könnyü vagy nehéz, multat s jövőt még nem festett az ész, idő nem volt, csak az örök jelen, mely, mint a pont, kiterjedéstelen s mert kezdettelen, így hát végtelen mi áll, vagy mozdul, minden névtelen, fü, fa, füst.

A tarka egység részekké szakadt, rámzúdult a különbség-áradat.

Képzelj faágakat: mindegyiken sok két- és hárommagvú tok terem: így lett lassacskán mindennek neve párjával: tej-víz, fehér-fekete, orr-fül, huszár-baka, fésü-kefe s hármasban: elefánt-zsiráf-teve, fü, fa füst. (Weöres, 2009, I., 158-160. o.)

Elsődleges olvasatban az időtlen és névtelen ős-egység éppen azáltal bomlik fel, hogy azt az értelem a szó által megfogja [névtelen $\rightarrow$ neve (lett)]. A textus keleti beágyazottságát tovább erősíti a denotatív aktus faszerkezethez való hasonlítása, amely a dharma ${ }^{27}$ fájának ${ }^{28}$ képzetére íródik rá: ennek egyik ága a 'vácsanika-tapasz', azaz a szó és a beszéd leküzdése önfegyelmezés, önmegtartóztatás, aszkézis útján. ${ }^{29}$

A megszólaló ennek utána visszatérni látszik a narratív vázhoz (5. versszak), ám az azt követő zárlatban (6. és 7. szakasz) már az aktuális jelent, vagyis a vers megírásának 
pillanatát rögzíti. A közvetve visszaemlékező, primer szinten rekonstruktív alaphelyzet („Ekképp mesélték, csak innen tudom [...]”.) fokozatos felszámolódását a Fü, fa, füst jelen idejü igealakjainak feltünése jelzi:

Sorsom huszonnégy esztendőt lerótt, még végigélnék néhány-milliót: hasztalan vággyal nézem a jövőt, gyerek áll így a más-cukra előtt.

s ezzel párhuzamosan a megnevezés negatívumként való értékelése is kétségessé válik:

De a kevés is jobb, mint semmi se, az élet szép, csak bánni kell vele $\mathrm{s}$ ha félrebillen kedvem kereke, helyrezökkenti a varázsige: fü, fa, füst.

Szép a való! szebb, mint minden mese, kár, hogy mindünknek hütlen kedvese. Azért van mind a tétlenség $\mathrm{s}$ a tett, hogy tompultabban várd a végzeted. Kinn ülök most a híg téli napon, mint aranya körében Harpagon s ha mennem kell majd: tenger vagyonom bucsuzóul még összeszámolom: fü, fa, füst.

Miközben tehát a lírai beszélő eredeti retorikai stratégiájának megfelelően a nyelvi cselekvés megismerést gátló szerepét igyekszik bizonygatni („Szép a való! szebb, mint minden mese, / kár, hogy mindünknek hütlen kedvese.”; „Azért van mind a tétlenség s a tett, / hogy tompultabban várd a végzeted.”), vagyis egy filozófiai tétel versszöveggé transzponálására törekszik (második szintü rekonstrukció), megnyilatkozását minduntalan áttörik az ebböl kimutató szemantikai egységek („De a kevés is jobb, mint semmi se, / az élet szép, csak bánni kell vele.”), nyelvi elemek: utóbbi esetben éppen az a három szó, amely bár a megnevezés hiábavalóságának folyamatát elindította, mégis mint megörzendő varázsige, s nem mint annullálandó, a tiszta létszemléletet gátló eszköz értékelődik (,,[...] az első, amit kimondott a szám: / fü, fa, füst.”; ,[...] s ha mennem kell majd: tenger vagyonom / bucsuzóul még összeszámolom: / fü, fa, füst.”). Az eddigiekből következik, hogy a kétirányú rekonstrukció a második szinten kudarcba fullad, ami az értelmezés folytatására szólítja fel az olvasót.

Weöres verse két ütemü tízesben íródott; a szótagszám megszegésére, ezáltal az ütemhangsúly megváltozására sehol sem találni példát. Az automatizmust tovább fokozza az ütemhatár döntő többségben szóhatáron való realizálódása; feltűnő azonban, hogy ezen szabály áthágásai a vers kompozicionális szempontból kiemelt pontjaira, azaz a felütésre, a vers centrumára és a zárlatra korlátozódnak. A középső (4.) versszak nyolc sorából ötben szóközepi a metszet ${ }^{30}$, vagyis a hindu világszemlélet tárgyalt tételét a téma szintjén leginkább színre vivő szakasz innen való értelmezhetősége a ritmus tökéletességének megtörése által látszólag visszaigazolt. Az $5 \| 5$ osztatú tízes ütemhatárának első szóbelseji feltünése azonban a nyelv ösi tömörségének felbomlását, s annak tagoltba való átmenetét a szülőkön keresztül közvetített nyelvi hagyomány elsajátításához köti: 
[...] az „,ee-ee” és ,pa

az első, amit kimondott a szám:

„fü, fa, füst”.

így a vers centruma inkább a hétköznapi kommunikatív nyelv kiépülésének expanziójaként - s kevésbé egy filozófiai tétel illusztrációjaként - írható le. Eme interpretációt támogatja az emlékezet versszövegbeli megközelítésének kétfajta módja is: míg a mindennapi nyelvhasználat puszta emlékátadáson alapul $(,,[\ldots]$ emlékezés sem kísér az uton - / Ekképp mesélték, csak innen tudom [...]”.), addig a perszonális az emlékezet visszaszerzésének aktusán: „És egy nap - tisztán emlékszem reá - nem fértem állva az asztal alá.” Mindezt a már említett nyelvi idősík-váltás (múlt idő $\rightarrow$ jelen idő) követi, ami a megnyilatkozás temporális struktúráját és a megnyilatkozó beszédét az írásaktus terébe emeli. Az így létrejövő tér pedig maga a megszületése közben lévő szöveg, azaz a $F u ̈$, $f a$, füst című vers. A refrén szemantikai íve tehát a nyelvi tradíció közvetített elsajátításától (szülők emlékezete, epizodikus emlékezet) a kommunikatív nyelv egyeduralkodóvá válásán keresztül (4. versszak) a költői beszédmód megvalósultságáig terjed (szemantikus emlékezet). ${ }^{31}$ Utóbbi értelmezést erősíti az a tény, hogy a varázsige szó kétszer tủnik fel a versszövegben, mindegyik alkalommal a refrénhez kapcsolódóan: a tizenhetedik sorban az első alanyi és ebben az értelmezési hálóban lírai megnyilatkozás („,fjü-ffa-fjtt”) környezetében, míg a hatodik szakaszban annak letisztult változatát bevezetve. A refrén gügyögésszerü és torzult alakja tehát nem kifejezetten interpretálható gyermeknyelvi elemként; éppen ellenkezőleg, azt a nyelv energeia-természetében gyökerező folyamatot viszi színre, amelynek köszönhetően a magyar költészet történetében eleddig ismeretlen nyelvi-szemantikai alakzat jön létre. ${ }^{32}$ Ennek során a fü, a $f a$ és a füst szavak a verses megnyilatkozás metanyelvi eszközeivé válnak, azaz jelentésmezejük jelentősen megváltozik és kitágul. ${ }^{33}$ Nem véletlen, hogy a textus egyetlen belső ríme a 'faág' lexémát, utolsó metszetszabály-sértése pedig az 'arany' szót is magában foglaló sort emeli ki. Míg az egyik nyelvi elem az ígéret, addig a másik a már létrejött teljesítmény pozitív szimbóluma: ${ }^{34}$

A tarka egység részekké szakadt, rámzúdult a különbség-áradat. Képzelj faágakat [...].

$[\ldots]$

Kinn ülök most a híg téli napon, mint aranya körében Harpagon s ha mennem kell majd: tenger vagyonom bucsuzóul még összeszámolom: fü, fa, füst.

Ezért is lehet annyiban egyetérteni Bata Imrével (1979, 11-13. o.), hogy Weöres verse nyelvteremtésként határozható meg. A 'fa' hangzásegység sorozatos rekurrenciája (almafa, fa, faág) ugyanis a konvencionálistól elszakadó jelentés nyelvi lehetőségére irányítja a figyelmünket, arra, amit Vigotszkij a következőképpen foglal össze:

„A szóegyesülésnek azt a sajátos módját, amelyet az egocentrikus beszédben figyeltünk meg, az értelem befolyásának neveztük, s itt egyszerre gondoltunk a szó elsődleges, betü szerinti jelentésére [...] és átvitt, általánossá vált jelentésére. Az értelmek mintegy egymásba folynak és mintegy hatnak egymásra, így az előzők 
mintegy bennfoglaltatnak az utánuk következőkben vagy módosítják azokat. Ami a külső beszédet illeti, hasonló jelenségeket különösen gyakran figyelhetünk meg a költői nyelvben. A szó valamely irodalmi alkotáson keresztül haladva magába szívja az abban rejlő értelmi egységek sokféleségét és értelmére nézve szinte egyenértéküvé válik a mü egészével. Ezt igen könnyü megvilágítani az irodalmi müvek címével." (Vigotszkij, 1967, 382. o.)

A Vigotszkij által leírt müködésmód tehát nemcsak elérhetővé teszi a beszélő számára a körülötte lévő világ megértését, hanem ki is jelöli annak módját. A jel használata nem zárja el a beszélőt a hermeneutikai aktustól: az epizodikus emlékezet szemantikusba fordítása egyben a költői nyelvre és szóra való alkotó emlékezés, a lírai megszólalás lehetőségének visszanyerése. ${ }^{35}$

\section{Diskurzusrendek a Tóth Krisztina-önreflexióban és -kritikában}

Weöres Sándor és a fejezetcímben említett szerző életművének befogadástörténete talán azért, mert a korai Tóth-recepció az Őszi kabátlobogást és az azt követő versesköteteket makacsul az újholdas hagyományáramba illesztette ${ }^{36}$ - meglepő hasonlóságokat mutat. A fenti folyóirat szinte alapításának pillanatában többek között éppen a Weöres-líra jegyében és ellenében határozta meg önmagát, ${ }^{37}$ így Tóth Krisztina vonatkozásában például a személytelenség és a személyesség vissza-visszatérő kérdésköre, ${ }^{38}$ a ritmus funkciójának szakadatlan újrapozícionálása, a tradícióhoz való viszony nem lankadó tematizálása ${ }^{39}$ egy olyan - folyamatosan kiépülő - hagyománytengely mentén történt meg, amely innen nézve a Nyugattól (és Weöres Sándortól) az Újholdon át napjainkig ível. Eme hagyománytengely felrajzolóinak kritikai szóhasználata adott korpuszra mint arra Kulcsár-Szabó Zoltán a csöngei születésü lírikus kapcsán rámutat ${ }^{40}$ - könnyen rázáródik ${ }^{41}$, számomra mégsem tünik haszontalannak a Tóth-önreflexiót egy rövid kitérő erejéig a Tóth-kritika néhány sarkalatos észrevételével és a weöresi poétikával összevetni, hiszen ezen összevetésből a fő témára, azaz az emlékezésre nézvést is komoly következtetéseket lehet levonni.

A két költészetfelfogás közötti egyik legszembetűnőbb hasonlóság a költőszerep értelmezését nagyító alá véve mutatható ki. Köztudott, hogy Weöres hárítani igyekezett magától mindenfajta képviseleti attitüdöt, amitől - igaz, kortársi szituációhoz igazítottan - Tóth Krisztina véleménye sem áll távol: Tóth ugyanis nemcsak a posztmodern már-már kiüresedett, automatizált, irónián nyugvó nyelvkritikai szemléletének érvényességét kérdőjelezi meg, hanem a küldetéses líra legitimációját is:

„Amúgy is roppantul idegesít a klasszikus felosztás, mely szerint egyfelől ott áll a megfáradt, szkeptikus, cinikus nyelvkritikai szemléletű költő, másfelől az elmebeteg küldetéses, akiben fel sem merül, hogy a nyelv már kiüresedett, nagy lánglelküen csak mondja a magáét, és azt hiszi, hogy még mindig mennek utána, de hátra nem nézne a hülyéje. Aki verset ír, az valamilyen szinten mindig meg van győződve, hogy fontos és komolyan veendő, amit csinál. Kemény Pistát igazán nem lehet a küldetéses költők közé sorolni, mégis azt írja: »De én tudom, mert én költő vagyok / Emlékszem, hiszen az irigye voltam. / Emlékszem, úgy hívtuk, hogy én.«" (Lackfi, 2003, 92. o.)

Fontos megjegyezni ugyanakkor, hogy a (vers)nyelv mint az egyént megnyilvánító közeg soha (sem a költeményekben, sem az elméleti reflexióban) nem kerül egyértelmüen negatív kontextusba ${ }^{42}$, azaz az önkimondás lehetségessége előtt nem záródik el az 
út: a hagyományhoz való alkotó nyelvi viszonyulás ${ }^{43}$ kiutat látszik kínálni a 20 . század harmadik harmadában uralkodóvá váló szkeptikus paradigma hatóköre alól, miközben az intertextuális játék sem a megszokott, a szöveg koherenciáját, önazonos voltát megbontó entitásként tételeződik:

„Nyilván bizonyos távolságból szemlélve minden pályakezdő nemzedéknél szembeötlőbbek a hasonlóságok és az egyedi vonások csak később válnak markánssá, mégis azt érzem, hogy a hiányretorika önismétlö eszköztára kimerülőfélben van. Szoktam ezen gondolkodni, mert ez nekem gond. Hogy jó, de akkor vajon milyen alternatív pozíciói lehetnek a kortársi megszól[aló]nak az állandó, finom kívülálláson és a nézőpontok relativizálásán túl, vagyis mit tegyen, ha azt érzékeli, hogy az irónia már nem csak költői pozíció, hanem egyezményes versgeneráló módszer? Az újraolvasás, újraértelmezés, a felhalmozódott kulturális örökséghez való elfogulatlan (nem ironikus, de nem is távolságtartóan tisztelettudó) visszakapcsolódás szerintem az egyik lehetséges tapogatózási irány. Az ironikus reflektálás másik végpontja nem feltétlenül valami sótlan normatív akadémizmus, inkább egy olyan eklektikus versnyelv, ami a különféle nyelvi rétegeket és irodalmi allúziókat a lehető legtermészetesebben keveri." (Tóth, é. n., 4. o. $)^{44}$

A tradíció tehát Tóthnál (é. n., 26. o.) is - csakúgy, mint Weöresnél ${ }^{45}$ - természetes közege a lírai megnyilatkozásnak ${ }^{46}$, olyannyira, „hogy a különféle sokszor egymásnak ellenmondó kánonok ellenére a versre és a szerzőkre - ha akarják, ha nem, ha vállalják, ha nem - a teljes bennük élő nyelvi kulturális örökség hat, minden véletlenszerüen fölmerülő vagy tudatosan parafrazált, intertextualitásba emelt elemével”.

A felvázolt viszonyrendszerbe a Weöres-poétika főbb vonásaival szinte teljesen megegyező módon illeszkednek a szerző költeményről, alkotói folyamatról, illetve lírai dikcióról, vershangzásról ${ }^{47}$ tett megjegyzései. A versírás Tóth Krisztina szerint sem közelíthető meg a romantikus zseni-eszmény, valamiféle szabályrendszer vagy a gondolatközlés szándéka felől, hiszen az inkább a csináláshoz, a készítéshez mint a semmiből való teremtéshez áll közelebb. ${ }^{48}$ Mindemellett a forma nemcsak a gondolattól nem választható el, hanem a verstől sem $^{49}$, ennek egyik összetevője, a rím pedig elöre nem látott energiákat szabadít fel:

„[...] nagyon sokszor úgy érzem, hogy a nyelv maga vezet rá dolgokra. Nem az a kiindulási pont, hogy szeretnék mondani valamit, és ehhez felhasználom a talált érdekességeket, hanem valami önműködő folyamat vezet el az egybeesésekhez. Ugyanígy áll ez a rímmel is: legtöbbször nem én találom a rímet, hanem ő talál rám." (Lackfi, 2003, 94. o. $)^{50}$

Következésképpen a létrejövő nyelvi teljesítménynek - a szövegben megképződő egyszeri jelentésnek ${ }^{51}$ - egészen más valósága van, mint a szétszabdalt tapasztalatnak ${ }^{52}$, vagyis a Tóth Krisztina-féle versnyelvre is igaz, hogy az a múlt megközelítésének teljesen más módját teszi nyilvánvalóvá. Így megkerülhetetlen annak rövid áttekintése, miként függ össze az emlékezet/emlékezés kérdésköre az eddig mondottakkal, s milyen nézőpontok merültek fel ezzel kapcsolatban az elemző gyakorlatban.

A kritika a kezdetektől fogva tisztában van azzal a ténnyel, hogy az előbbi tematikus paradigma problematikussága a Tóth Krisztina-korpusz egyik középponti markere, ${ }^{53}$ éppen ezért nem olyan meglepő, hogy - hasonlóan a nyelvkritikai alapállást túlhangsúlyozó interpretatív vonulathoz - az életmüvet körülvevő másodlagos irodalomban „az emlékezet munkája irányíthatatlan áradatként" (Keresztesi, é. n. $)^{54}$ van jelen. Dolgozatom témája felől nézve sokkal érdekesebb ennél Prágai Tamás tanulmánya, amelyben 
a szerző Platón, Derrida és Freud írásai alapján értelmezi a Porhó című kötet emlékezetkonstrukcióit: meglátása szerint az emlékezetben személyessé válik a külső, „csak eltelt" idő, amit a versnyelv sajátos szintaktikai-grammatikai rendje, hétköznapi kommunikatív formáktól, valamint logikai ítéletektől eltérő karakterisztikuma tesz lehetővé. Mivel - mint mondja - a „,mondatsorokat keresztülöltő, vagyis a grammatikai mondatot felszámoló" pontozás a Havak éve címü ciklusban uralkodóvá válik, ,a[z olvasói] figyelem a poézisként létező szöveg sajátosságaira irányul" (Prágai, 2002, 119-120. o.). ${ }^{55}$ A lírai megnyilatkozás, s annak saját immanens rendje tehát - ahogy az Weöresnél is tapasztalható volt - a lehető legszorosabban korrelál az emlékezés problémakörével, az emlékezet szerveződésével. Ám Tóth Krisztinánál az emlékezet/emlékezés primer, jelölt módján túl számolni kell emezek egy sokkal rejtettebb megnyilvánulási módjával, azaz a szöveg emlékezetével is. Az utolsó fejezetben erre igyekszem három mikroelemzéssel megtámogatott példát felhozni.

\section{A szöveg mint emlékezet. Tóth Krisztina: Csónak, Porhó, Évszakok zsoltára}

Az alábbiakban tárgyalandó költő esetében nemcsak az elméleti reflexió szolgál bizonyítékul arra, hogy a kortárs életmü egyik fontos összetevője a Weöres-szövegmező ${ }^{56}$, hanem az előd nevét az ajánlásban vagy a textusban kiemelő lírai darabok is. A már idézett Hála-változaton túl ide tartozik a Csónak, amely meglátásom szerint a csöngei lírikus Csónakok címü írására reflektál:

\section{Weöres Sándor \\ Csónakok}

A csónakok úsznak.

A halk csónakok úsznak.

A csónakok halk vizen úsznak.

Csónakok érkeznek, csónakok bucsúznak.

A nap sugarában ébredeznek, a hold sugarában alusznak.

A csónakok tizezer éve úsznak.

Tavon, folyamon, tengerhabon érkeznek, bucsúznak.

A csónakok halk vizen úsznak. A halk csónakok, tizezer évig.

A csónakok úsznak.

(Weöres, 2009, III., 232. о.) 


\section{Tóth Krisztina \\ Csónak}

\section{W. S.-nak}

Figyelnek éjszaka óriási szem halad gyanútlan színeden érintetlen folyó hatalmas csónakon álmatlan földgolyó a nyitott szem maga időtlenül halad

Ahol az egyik ür a másik ürbe ér zuhatagos sötét viszi a csónakot és az álmatlan út végtelen álma ott újabb sötétbe és mélyebb álomba ér

Weöres Sándor verse - akárcsak a Fü, fa, füst - jól olvasható a keleti filozófiai tradíció felöl, hiszen címe a taoista hagyomány egyik központi fogalmát, a csónakot ${ }^{57}$, szövege pedig az abban gyakran előforduló tízezres számot ${ }^{58}$ tárja szinte ellenállhatatlan erővel az értelmező elé. Mindemellett a csónak majdnem minden kultúrában a más létformába való átjutást biztosító eszköz: túlvilággal való összekötő szerepe miatt keleten is felbukkanik a halál és a megtisztulás misztériuma körül, így Weöres textusában a csónak és a tízezer év végső soron a transzcendens lét felé úton lévő ember metaforája. Emiatt lehet a versben annyira erős a vízképzet, $\mathrm{s}$ emiatt - mintegy az élet hányattatásait jelképezendő - fordul elő abban a víz három megjelenési formája is (tó, folyam, tengerhab).

Hogy Tóth Krisztina költeménye tematikus szinten ráíródik a Csónakokra, evidens, hiszen előbbibe a centrális szerepet betöltő tárgy mellett (csónak) az éjszaka és a folyó, folyam szemantikai mezeje is átemelődik. Ám a keleti filozófiai háttér Tóthnál elmosódik, jelenlétét csak nagy nehézségek árán lehetne kimutatni: a Prágai Tamás által definiált poétikai eszköz azonban, vagyis a központozás hiánya lehetővé tesz egy olyan olvasatot, amelynek közvetlenül a költőelödöt megszólító megnyilatkozás is része: „,maga időtlenül halad". Ráadásul a Csónak beszélöje retorikailag elkülöníti önmagát a többiektől, hiszen az odafordulással jelzi, hogy a „Figyelnek” hatókörén kívül tartózkodik („Figyelnek” $\leftrightarrow$ „,maga időtlenül halad”): a lírai alany az élö irodalom okán mind a[z elmarasztaló] kritikai diskurzus értelmében vett, mind a politikai indíttatású figyelmet (megfigyelés) ignorálja ${ }^{59}$, s rámutat, hogy a számára fontos korpusz akkor is eleven, ha azt ideológiailag vagy kritikailag támadják. Ezzel létrejön az a viszonyrendszer, amit Lotman a szöveg emlékezetének nevez ${ }^{60}, \mathrm{~s}$ a 'csónak' szó jelentése is megváltozik, azaz a Weöres-életmü metaforájává lép elő (a váltást grammatikailag a többes számú cím egyes számúra cserélése jelzi: Csónakok $\rightarrow$ Csónak). A hagyomány visszanyeréseként funkcionáló konstruált szövegemlékezet ereje olyan expanzív, hogy a halálképzetet is felülírja ${ }^{61}$ : a mélyebb álom ugyanis ebbe az interpretatív keretbe nem az elmúlás szemléletes leírásaként illeszkedik, hanem a pretextusháló legteljesebb átsajátításaként. A mottóként kiemelt két idézet innen nyeri el az értelmét: láttuk, mindkét költő újra és újra visszatér egy-egy problémához, számára megkerülhetetlen kérdéshez, ám a visszatérés okaként nemcsak valamely traumatikus esemény vagy filozófiai probléma (idő múlása, halál, elválás stb.) adható meg, hanem a hagyomány újragondolása is ${ }^{62}$ : mert a szöveg emlékezete ${ }^{63}$, csakúgy, mint a nyelv, amely azt létrehozza, nem ab ovo adott. ${ }^{64}$ A 'csónak' szavunknak a kortárs költő nélkül nem lenne a fentiekben leírt jelentése. 
A Porhó, amely a Tóth Krisztina-életmúvet összefoglaló kötet címadó verse, formailag a Születésnapomra íródik rá. Eme formai tradíció jelenléte a Tóth-költeményben olyanynyira domináns, hogy a kritika kizárólag a József Attila-i hagyomány és a szövegben tagadhatatlanul jelen lévő melankolikus-személyes idő- és múltértelmezés felől közelítette meg a szóban forgó textust. A vers zárlata viszont egy kevésbé explicit, de annál jelentősebb vonatkozási mezővel is rendelkezik, s e tény egészen másféle interpretatív utat képes megnyitni.

\section{Tóth Krisztina Porhó}

Harminckettő hogy telhetett?

Hogy múltak el napok, hetek?

Letelt,

s hitelt

nemigen ad már a jelen.

Nem voltam benne még jelen, úgy múlt

a múlt,

annyi idő, hogy szinte sok.

De ért már más is, mint e sokk:

hold is,

nap is

pólyálta hülő életem,

$\mathrm{s}$ amit nem tettem, tervezem

e lét

felét

leélve: őrzöm arcomat,

s eleddig nem zuhant sokat

csecsem

becse,

sőt, egy bocsom is van (de szép!),

beszélni is kezd majd ez év

telén

talán,

de hogy mit történt, mire volt jó harminckét éven át a porhó, havam, hevem

hová gomolygott nyomtalan, és ugyan hol, ha nyoma van, szivek, szavak 
mélyén mi ülepszik, mi lesz,

így fog eltelni, élni ez?

Vagy túl

a túl

bonyolult léten, túl ezen

egyszercsak majd megérkezem

s ittlétemet

átlátom ott?!

(Tóth, 2001, 54-55. о.)

A Porhó utolsó két versszaka Weöres Sándor Túljára, valamint De profundisára egyidejüleg reflektál, amivel a közöttük feszülö szemantikai ellentétet elsimítja, de legalábbis tompítja. Sőt, a vázolt eljárással olyan hagyománysor teremtődik, amely a szokásos kritikai diskurzuson kívül van (József Attila, Weöres Sándor, Tóth Krisztina), így a múlt és az idő átértelmezése a tradíció reinterpretációjává válik. Vagyis a Porhó úgy is elgondolható, mint a hagyomány mibenlétének reflexiója. A szövegemlékezet itt e reflexióban gyökerezik, ami a „Nem voltam benne még jelen” típusú markáns kijelentést is képes annullálni.

\section{Túl}

Fönn lakik a csillagsereg,

a rét,

a réten túli rét.

A hó,

a havon túli hó.

A jég,

a jégen túli jég.

A föld,

a földön túli föld.

Az ég,

az égen túli ég.

A túl,

a mindenen túli túl.

A túl.

(Weöres, 2009, III., 363. о.) 


\section{De profundis}

(részlet)

Léten túl is, ha szétnyílt a fátyol, majd e világ-mélyi utazástól reszketek, tudom.

Menny sem adhat már nekem nyugalmat:

Isten fénye közt is e siralmat mindig jajgatom.

(Weöres, 2009, I., 201-203. о.)

Ezzel megegyező működésmód figyelhető meg az Évszakok zsoltára esetében is. A Lator Lászlónak ajánlott vers Weöres Sándor Valse triste és Ének a határtalanról címü szövegét egyaránt hagyománytörténésbe emeli: Tóth Krisztina írása az előbbiből az emlék/ emlékezet negatív kontextusba való tematikus beágyazottságát, míg az utóbbiból egy grammatikai szerkezeten túl ${ }^{65}$ az évszakok örök körforgását veszi át. Ráadásul a Valse triste A négy évszak alcímet viselő Első szimfónia harmadik tétele, így az Évszakok zsoltára hozzá való csatlakozása innen is motivált. Miközben tehát a versbéli beszélő retorikai stratégiája szerint az emlékezet kényszerességét bizonygatja (,nem emlékszel és semmit sem feledhetsz"), addig a szövegemlékezet alanya a primer emlékezet sugallta negativitást egyértelmüen felülbírálja, amennyiben a hagyomány implicit megidézésével nemcsak a Lator-lírát szólítja meg, hanem a Weöresét is (,tebenned fáztunk eleitöl fogva"). Vegyük észre, a lírai alany a zárlatban megtér (!): a kijelentés kettős értelme ('odajárul, elhagyja korábbi életét') olyan szemantikumot fed, amely a hagyományhoz forduló szövegemlékezetet a szakralitással helyezi közös nevezőre. Innen nézve az emlékezet/emlékezés Tóth-költeményben való részletezése egyáltalán nem destruktív, traumatikus vagy dekoncentrált, hiszen a szövegjelentés ellenáll ezeknek: a textus emlékezete maga a visszavonhatatlan jelenlét.

\section{Évszakok zsoltára}

A nyolcvan éves Lator Lászlónak

Lassított visszanézett forgó bicikliküllő-íriszével erdőkön gördülő földeken túli kék jel

ezer esztendő is csak rövid vigyázása egy éjnek futó patakok és szavak alatti ének

ez volt a tavasz és most már mindig ez lesz nem emlékszel és semmit sem feledhetsz

mikor még hegyek se voltanak útjaink kezdetén szemcsés vályogfalat tapogatott a fény

izzadt naptenyerét délben a füre rakta ez volt a nyár kerek világ lecsukott szemü arca egyetlen ijedt pillanat és most már mindig ez lesz nem emlékszel és semmit sem feledhetsz 
vagy a meztelen szárú ősz a kéményben baglyot találtak és visszaszállt a füst szaga tarlónak és halálnak

emberek jöttek-mentek nyitva hagyták az ajtót kezeink munkáit igazgassad harang szólt

az a kihülö kályha lett az ösz és most már mindig ez lesz nem emlékszel és semmit sem feledhetsz

pillákra ült a dér árkokba megfagyott hó minden dolgunk között vakon rohanni volt jó

huzatos hajlékunkba megtérni fogvacogva tebenned fáztunk eleitől fogva. (Tóth, 2009, 12. o.)

\section{Weöres Sándor Valse triste}

Hüvös és öreg az este.

Remeg a venyige teste.

Elhull a szüreti ének.

Kuckóba bújnak a vének.

Ködben a templom dombja, villog a torony gombja, gyors záporok sötéten szaladnak át a réten. Elhull a nyári ének, elbújnak már a vének, hüvös az árny, az este, csörög a cserje teste. Az ember szíve kivásik. Egyik nyár, akár a másik.

Mindegy, hogy rég volt, vagy nem rég. Lyukas és fagyos az emlék. A fákon piros láz van. Lányok sírnak a házban. Hol a szádról a festék? kékre csípik az esték. Mindegy, hogy rég, vagy nem rég, nem marad semmi emlék, az ember szíve vásik, egyik nyár, mint a másik. Megcsörren a cserje kontya. Kolompol az ősz kolompja. A dér a kökényt megeste. Hüvös és öreg az este. (Weöres, 2009, I., 107. о.) 


\section{Weöres Sándor}

\section{Ének a határtalanról}

Amikor még senkise voltam, fény, tiszta fény, a kígyózó patakokban gyakran aludtam én.

Hogy majdnem valaki lettem, kő, durva kö, hegylejtőn jég-erezetten hömpölygetett nagy erő.

És végül élni derültem, láng, pőre láng, a szerte határtalan ürben mutatom valódi hazánk. (Weöres, 2009, III., 135. о.)

\section{Irodalomjegyzék}

A feledésre ítélt költők ébresztgetője. (1993) Polner Zoltán beszélgetése Weöres Sándorral. In: Domokos Mátyás (szerk.): Egyedül mindenkivel. Weöres Sándor beszélgetései, nyilatkozatai, vallomásai. Szépirodalmi, Budapest.

A költészet hivatása. (1993) Tardos Júlia beszélgetése Weöres Sándorral. In: Domokos Mátyás (szerk.): Egyedül mindenkivel. Weöres Sándor beszélgetései, nyilatkozatai, vallomásai. Szépirodalmi, Budapest.

A legmagasabb bölcsesség gyémántvágójának szútrája (Vadzsraccshedika Pradzs-nyápáramitá Szutra). http://www.freeweb.hu/tarrdaniel/ documents/Mahayana/gyemantszutra.htm

A vers mint impulzus. (1993) Perneczky Géza rádióbeszélgetése Weöres Sándorral. In: Domokos Mátyás (szerk.): Egyedül mindenkivel. Weöres Sándor beszélgetései, nyilatkozatai, vallomásai. Szépirodalmi, Budapest.

Ablak négyszögében. (2003) Domokos Mátyás beszélgetése Weöres Sándorral. In: Domokos Mátyás (szerk.): Öröklét. In memoriam Weöres Sándor. Nap, Budapest.

Assmann, J. (2004): A rituálistól a textuális koherenciáig. In: Uö: A kulturális emlékezet. Írás, emlékezés és politikai identitás a korai magaskultúrákban. Atlantisz, Budapest.

Baktay Ervin (é. n.): Szanatána Dharma. Az örök törvény. A hindu világszemlélet. K. n., h. n.

Balassa Péter (1990): A mint B. Weöres Sándor Átváltozások című szonettciklusának elemzése. In:
Domokos Mátyás (szerk.): Magyar Orpheus. Weöres Sándor emlékezetére. Szépirodalmi, Budapest.

Bata Imre (1979): Weöres Sándor közelében. Magvető, Budapest.

Benkő Loránd (1984, föszerk.): A magyar nyelv történeti-etimológiai szótára. I-III. Akadémiai, Budapest.

Bertha Zoltán (1990): „múlónak látszik és örök”. Jegyzetek egy kis Weöres-remekmühöz. In: Domokos Mátyás (szerk.): Magyar Orpheus. Weöres Sándor emlékezetére. Szépirodalmi, Budapest.

Boros Oszkár (2006): Versnyelv és identitás (Weöres Sándor: Harmadik szimfónia). In: Horváth Kornélia és Szitár Katalin (szerk.): Vers - ritmus - szubjektum. Müértelmezések a XX. századi magyar líra köréböl. Kijárat, Budapest. 434-464.

Boros Oszkár (2011a): Retorika és versritmus. Weöres Sándor: A vers születése - Kovács András Ferenc: De profundis. In: Boros Oszkár, Érfalvy Lívia és Horváth Kornélia (szerk.): Ritmikai és retorikai tradíció a kortárs magyar lírában. Ráció, Budapest. 36-50.

Boros Oszkár (2011b): A ritmus mint intertextualitás és tradíció (Babits Mihály, Weöres Sándor, Parti Nagy Lajos). Kalligram, 3. sz. 84-89.

Csobánka Zsuzsa (é. n.): Szabadesés, hátborzongatás. Tóth Krisztina: Magas labda. http://www.prae.hu/ prae/articles.php?aid $=2536 \&$ cat $=3$

Graham, A. Ch. (1995): Lie-ci. A tao könyve. Farkas Lörinc Imre, Budapest. 
Gyémánt szútra. (é. n.) In: Bánfalvi András (szerk.) Mahájána buddhista szentiratok. Farkas Lörinc Imre, Budapest.

Halmai Tamás (2008): A szeretet mitológiája. Tóth Krisztina: Bárka. In: uő: Versnyelvtanok. Elemzö esszék kortárs versekröl. Vigilia, Budapest. 100-106.

Hamvas Béla (1990): A medúza. In: Domokos Mátyás (szerk.): Magyar Orpheus. Weöres Sándor emlékezetére. Szépirodalmi, Budapest.

Horváth Kornélia (1999): A Kettő és az Egy (Weöres Sándor: Keleti elégia). In: uő: Tühegyen. Versértelmezések a későmodernség magyar lírája köréböl: József Attila, Pilinszky János, Weöres Sándor, Nemes Nagy Ágnes, Petri György. Krónika Nova, Budapest. 77-97.

Írószobám. (1993) Simon István beszélgetése Weöres Sándorral. In: Domokos Mátyás (szerk.): Egyedül mindenkivel. Weöres Sándor beszélgetései, nyilatkozatai, vallomásai. Szépirodalmi, Budapest.

Jász Attila (2002): Fonalvezetés. Tóth Krisztina költészetének alakulásához, a Porhó-kötet kapcsán. Jelenkor, 12. sz. 1326

Juhász Attila (2010): Láng-nyelv, föld-nyelv, titoktartóedény. Új Forrás, 8. sz. 54.

Juhász Emese (1995): Tóth Krisztina: A beszélgetés fonala. Jelenkor, 5. sz. 482.

Kabdebó Lóránt (1980): Kozmikus bukolika (Weöres Sándor lírájáról). In: uő: Versek között. Tanulmányok, kritikák. Magvető, Budapest.

Karinthy Ferenc (1993): Róma, 1948. In: Tüskés Tibor (szerk.): Weörestöl, Weöresröl. Nemzeti Tankönyvkiadó, Budapest.

Kenyeres Zoltán (1983): Tündérsíp. Weöres Sándorról. Szépirodalmi, Budapest.

Keresztesi József (é. n.): Sodrásban. Tóth Krisztina: Magas labda = http://magyarnarancs.hu/konyv/ konyv_-_sodrasban_-_toth_krisztina_magas_labda71791

Keresztury Tibor (2002): A dolgok színe és visszája. Tóth Krisztina: Az árnyékember. In: uö: Kételyek kora. Tanulmányok a kortárs magyar irodalomról. Magvető, Budapest. 250-251.

Keresztül-kasul a költészeten. (1993) Kiss Károly beszélgetése Weöres Sándorral. In: Domokos Mátyás (szerk.): Egyedül mindenkivel. Weöres Sándor beszélgetései, nyilatkozatai, vallomásai. Szépirodalmi, Budapest.

Kulcsár-Szabó Zoltán (2013): A személytelenség kérdéséhez Weöresnél: Országút. Irodalomtörténet, 4. sz. 555.

Lackfi János (2003): A címzett ismeretlen. Beszélgetés Tóth Krisztina költővel. Új Forrás, 4. sz.

Lao-ce (1994): Tao Te King. Tericum, Budapest.

Lengyel Balázs (1946): Babits után. Újhold, 7. sz.
Lotman, J. (2002): A szöveg három funkciója. In: uő: Kultúra és intellektus. Jurij Lotman válogatott tanulmányai a szöveg, a kultúra és a történelem szemiotikája köréböl. Argumentum, Budapest. 32-33.

Margócsy István (2003): Tóth Krisztina: Porhó. In: uő: Hajóvonták találkozása. Tanulmányok, kritikák a kortárs magyar irodalomról. Palatinus, Budapest.

Nagy Boglárka (2007): Hétköznapi halálkozások. Tóth Krisztina: Siró ponyva. In: uő: Vándorló történetek. Kritikák a kortárs magyar irodalomról. Kijárat, Budapest. 46-56.

Negyvenhat perc a költővel. (1993) Cs. Szabó László rádióbeszélgetése Weöres Sándorral. In: Domokos Mátyás (szerk.): Egyedül mindenkivel. Weöres Sándor beszélgetései, nyilatkozatai, vallomásai. Szépirodalmi, Budapest.

Petri György (2007): „Költő vagyok - mit érdekelne engem a költészet maga?" (József Attila). In: uő: Munkái. Próza, dráma, vers, naplók és egyebek. Magvetö, Budapest.

Prágai Tamás (2002): Mnémoszüné arcai. Tóth Krisztina: Porhó. Kortárs, 6. sz. 119-120.

Rónay György (2003): A teljesség felé? Jegyzetek Weöres Sándor költészetéröl. In: Domokos Mátyás (szerk.): Öröklét. In memoriam Weöres Sándor. Nap, Budapest.

Schein Gábor (2001): Weöres Sándor. Elektra, Budapest.

Szávai Dorottya (2009): Az emlékező „Te”. Dialógus, emlékezés és temporalitás Tóth Krisztina költészetében. In: uő: $A$,,Te” alakzatai. Dialógus és szubjektum a lírában. Kijárat, Budapest.

Szentkuthy Miklós (1990): Weöres Sándor. In: Domokos Mátyás (szerk.): Magyar Orpheus. Weöres Sándor emlékezetére. Szépirodalmi, Budapest. 264 265.

Szmirnov, I. (1999): Úton az irodalom elmélete felé. Helikon, 1-2. sz. 113-114.

Szüts Terézia (2001): A vers kétarcúsága. Tóth Krisztina költészetéről. Mühely, 2. sz. 29.

Takács Ferenc (2009): A vallomás mestersége. Mozgó Világ, 9. sz. 115.

Tamás Attila (1978): Weöres Sándor. Akadémiai, Budapest.

Tóth Krisztina (1997): Az árnyékember. József Attila Kör - Kijárat, h. n. 44-45.

Tóth Krisztina (é. n.): Talált mondat. http://mta.hu/ data/cikk/ 10/75/1/cikk_107501/Toth_Krisztina.pdf

Tóth Krisztina (2009): Magas labda. Magvető, Budapest.

Tüskés Tibor (2003): A határtalan énekese. Írások Weöres Sándorról. Masszi, Budapest. 
Válaszolni nehezebb. (1993) Domokos Mátyás TVbeszélgetése Weöres Sándorral. In: Domokos Mátyás (szerk.): Egyedül mindenkivel. Weöres Sándor beszélgetései, nyilatkozatai, vallomásai. Szépirodalmi, Budapest.

Várkonyi Nándor (1990): A kozmikus költő. In: Domokos Mátyás (szerk.): Magyar Orpheus. Weöres Sándor emlékezetére. Szépirodalmi, Budapest.

Vigotszkij, L. Sz. (1967): A gondolat és a szó. In: uő: Gondolkodás és beszéd. Akadémiai, Budapest.

Visszaadni az embernek saját lehetőségeit. (1993) Tamás Menyhért beszélgetése Weöres Sándorral. In: Domokos Mátyás (szerk.): Egyedül mindenkivel. Weöres Sándor beszélgetései, nyilatkozatai, vallomásai. Szépirodalmi, Budapest. 132.
Vörös István (1994): Az érzelmek felparcellázása. Elmélet és gyakorlat Tóth Krisztina versei kapcsán. In: Károlyi Csaba (szerk.): Csipesszel a lángot. Tanulmányok a legújabb magyar irodalomról. Nappali Ház, Budapest. 117-118.

Weöres Sándor (1993): Megfejtés a Rejtelemre. Nyilatkozat. In: Domokos Mátyás (szerk.): Egyedül mindenkivel. Weöres Sándor beszélgetései, nyilatkozatai, vallomásai. Szépirodalmi, Budapest.

Weöres Sándor (2011): A vers születése. In: uő: Egybegyüjtött prózai írások. Helikon, Budapest.

Weöres Sándor (2009): Egybegyüjtött költemények. I-III. Helikon, Budapest.

Wen-Ce (1995): Lao-ce utolsó tanitásai. Farkas Lőrinc Imre, Budapest.

\section{Jegyzetek}

${ }^{1}$ A kutatás az Európai Unió és Magyarország támogatásával, az Európai Szociális Alap társfinanszírozásával a TÁMOP 4.2.4.A/2-11-1-2012-0001 azonosítószámú Nemzeti Kiválóság Program - Hazai hallgatói, illetve kutatói személyi támogatást biztositó rendszer kidolgozása és müködtetése konvergencia program címü kiemelt projekt keretei között valósult meg.

${ }^{2}$ Vö. „A megkövült pokol már nem mér bajra bajt, / csak asszonyom sürög, tükörben jár a hulla, / munkál, szerez, diszít; emelkedve-lehullva, / pokoli szélmalom kit lég hiánya hajt. // Ö egyhelyben szalad, én bensőmben szököm meg / zuzmarás ágyamról s tárúl az ősvilág / hol fiú-fog között ropogtak az atyák / nem várva meg élve jöttét a förtelemnek, // vagy torony-erkélyről szétnéztek a jövőben / hol elmúlt ártalom halk habot habra sző. / A térben csapdos ő; én ázom az időben. // Fölöttünk dermesztő dülledt Medusa-fö. / Szól: »Segíts magadon! Egy ajtót nyitva hagytam: / már les rád a titok. Hát nézd meg, jobb-e ottan.«" (Jelenlét; Weöres, 2009, II., 158-159. o.) „A Napnak ajánlottuk fel az első sziklát, a legközelebbit, szárny- / módra kitárt karjainkkal, a tüznek. / Míg a fehér madarak elhúzódtak / a hideg égtáj felé. / Ök, a ragyogó tollúak, a fagyot és sötétet keresték; minekünk / még nem volt repülésünk, csak álmainkban. / (Emlékszik a szikla, rajt véset mély csatornái.) / A kövek fölé mennyboltot vájtunk óriásira, hogy valahol elférjen / a tekintetünk. Fenn vitt az út, a megszökő szárnyasoké; mi lengő / karuak csak ugrálni tudtunk. / És e homorú bölcső mélyén aludtak csillagos éjszakáink. A Na- / pot imádtuk, az árnyra nem eszméltünk, a sötétség csak háló- / szobánk volt. / (Emlékszik a vésett szikla egyhelyben állva. De mi merrefelé / emlékezzünk, vissza, vagy elöre? Az idő-mutató mennybolt, amit / vájtunk, minden-irányú a tekintetünkben." (Kezdetben; Weöres, 2009, III., 7. o.) Vö. még: „Az óegyiptomi kultúra dinamikus fogalmat alkotott a világ lendületben tartásához szükséges erőfeszítésekröl. Zömmel rituális és szellemi természeti erőfeszítésekről van szó: a hagyományozott tudásépítmény helye nem annyira a könyvek, mint inkább a rítusok. Ha a rítusokat nem kifogástalanul hajtják végre, a Világ összeroskad, az Ég beomlik." (Assmann, 2004, 87. o.)

${ }^{3}$ Átmeneti véleményt fogalmaz meg Bata Imre (1979, 53. o.), aki Weöres nyomán kijelenti, hogy „a gondolati költészet [...] nem gondolatok megverselése".

${ }^{4}$ Különösen meglepőnek, már-már komolytalannak, feleslegesen kihívónak tünik alábbi mondata: „Engem a magam régi emlékei nem vonzanak, és különösen nem, hogyha a helyszín annyira átalakul." (Keresztül-kasul..., 1993, 312. о.)

${ }^{5}$ Értelmezői szempontból roppant tanulságos, Bata mely mondatait emeli ki könyvismertetőjében Tüskés Tibor (2003, 130. o.), vö. „A költészet az egészre való emlékezés [...]".

${ }^{6}$ Ezek a szövegek, csakúgy, mint a korábban idézett Jelenlét és Kezdetben, a primer olvasatok par excellence argumentumaivá váltak. Vö. „1. Ó, a jövendő könnyü lobogója! / minden jöhet: üdvösség, kárhozat. / Ó, a mult dombormüvü koporsója! / a sokból egy történt, nincs változat. 2. Minden csak önmagának talmi képe, / hisz elmállik, emléke sem marad; / de nézz a mult dermedt jégtengerébe: / ott megrögződött minden mozdulat. 3. Előbb elfújhatsz házat és hegyormot, / mint egy tegnap elhamvadt tollpihét. / Örök arcukat mutatják a dolgok / a múltban. Nem másít rajtuk a lét." (Orbis Pictus. A mult naplója; Weöres, 2009, II., 76. o.) Lásd még: „A föld, hol az élet terem, / a mindent nyelő sírverem, / a síkság, hegy, tenger, folyó: / öröknek látszik és muló. // Világür és mennyboltozat, / sok forgó égi kapcsolat, / a milliárdnyi tüzgolyó: / öröknek látszik és muló. // Mit eltemet a feledés, / egy gyík-kúszás, egy szárnyverés, / egy rezdület, mely elpörög: / mulónak látszik és örök. // Mert ami egyszer végbement, / azon nem másít semmi rend, / se Isten, se az ördögök: / mulónak látszik és örök." (Öröklét; Weöres, 2009, III., 151. o.) 
${ }^{7}$ „Sanyi kereken tagadta a fejlődés elvét a történelemben, szerinte [az] inkább körforgás vagy hullámmozgás, kultúrák felemelkedése és alásüllyedése, a világszellem felragyogása s elhalványulása." (Karinthy, 1993, 146. o.)

${ }^{8}$ Várkonyi Nándor nyomán. Vö. „Az ősköltő Weöres lírájának mindenkori hőse [...]" (Bata Imrét idézi: Tüskés, 2003, 130. o.).

${ }^{9}$ Lásd még: „Minél mélyebben haladunk vissza az időben, annál mélyebb értelmúek az összefüggések, annál bizonyosabb, valahol az idők mélyén - s ez a mélység az emberi tudat alatt vonul, húzódik öntudatlan - ott van a minta, a példa és a vigasztalás. A lírának majd az lesz a dolga, feltörni az ősfeledés burkát, felidézni az idők vonulását, magát a teljességet, korunk széthullott emberének megmutatni az integrált emberi teljességet. A káoszt, mely a jelen is, kozmosszá rendezni, mint volt az időnek előtte." (Bata, 1979, 24. o.) Vö. „És milyen a világ képe, mely Weöresben él? Megidézi az ősvilágot, lemerül a múltba, emlékeit, belső látomását, víziót vetíti ki, emberi szóval akarja megfogni a megfoghatatlant [...]." (Tüskés, 2003, 90. o.) „[Weöres verseiben] mitikus tér-idő-távlatok tárulnak elénk.” (Tamás, 1978, 19. o.) „A[z Átváltozások címü] ciklus szerkezete motivikus körforgás, körkörös, variatív ismétlés jegyében áll, ami egyúttal, a több ponton is utalt archaikus időfelfogásnak felel meg." (Balassa, 1990, 374. o.)

${ }^{10}$ „A megismerés pillanata is kettéhasadt, elveszett a szinkronicitás, és elveszett a világban a létnek és a tudatnak az ősi egysége [...]" (Ablak..., 2003, 261.o.).

${ }^{11}$ Hamvas Diáriumban közölt kritikája hosszú időre meghatározta a Weöres-líra befogadását, s olyan elváráshorizontot alapozott meg, amely máig kitapintható módon írja elő az életmű olvasását: „Irodalmunk története általában eddig olyan költőket emelt ki, akiknek költészete tárgyi és külső jellegü. Európában is így volt. A helyzet ma megváltozott. Elkezdték az olyan költőket előnyben részesíteni, akik a külső és tárgyi világot az eredetihez visszaviszik: elöször a belső képhez, aztán az érzékelhetetlen belső zengéshez, végül a transzcendens léthez. [...] Ebben a költészetben a dolgok, élmények, tárgyak és események külső volta teljesen felszívódik a megfoghatatlan irracionális létélménybe. Ebben a költészetben a világ visszatér ősállapotába: leveti külső és tárgyai voltát. Visszarealizálódik. Újra az lesz, ami: idea. Isten, Lét, Valóság.” (Hamvas, 1990, 215. o.) És később: „Viszszatértünk a költészet ősforrásához. A látszatmüvészetet nem tudjuk már komolyan venni. Keresztüllátunk rajta. Nem búbájos játékra van szükségünk, hanem költészetre. A költészet pedig orpheuszi: szent elragadtatás." (Hamvas, 1990, 217. o.)

${ }^{12}$ Magától értetődik, eme elkeseredettséget a nemtelen (kultúr)politikai támadások is táplálták.

${ }^{13}$ Bár Schein Gábor $(2001,98$. o.) nem az emlékezetről írja a következőket, könnyen belátható, hogy megállapításai arra is érvényesek. Vö. ,[...] a történelem itt már [vagyis a Psychében] nem csupán a világról alkotott diszkurzív tudás egyik, de nem egyetlen, és ezért viszonylagos formája, hanem olyan elbeszéléskonstrukció, amely bármikor szabadon kiegészíthető, átalakítható és felbontható, azaz olyan fikció, amelyre ugyan valóságként tekintünk, de mivel a valószerüség megalapozása mindig retorikai természetü, ezért csupán az elbeszélés által jön létre."

14 „Miképpen látszik egy élet a másik előtt? Megnyilvánulások sorozatában. De a megnyilvánulások között nincs folytonosság. Az élet mint látvány csakis diszkontinuus lehet.” (Bata, 1979, 309. o.)

${ }^{15}$ „A tapasztalat diszkontinuus világából megépül a szellem kontinuus rendje: nyelvi anyagból és ritmusból." (Bata, 1979, 51. o.)

${ }^{16}$ Például a Fü, fa, füst, illetve Az üres szoba elemzése során (vö. Bata, 1979, 12-13. o.; 46-47. o.).

${ }^{17}$ A logikai ugrást maga Bata is érzékelhette, ezért merül fel nála később, hogy az emlékezés konstruktív jellege egyfajta értékvesztés is egyben: „A megosztott, kettéhasadt sors [...] azt diktálja, csak az lehet, ami nincs, mert ami van, elmúlik, vagyis nincs lesz belöle. Ez a múlt idő. A van szüli a múltat, az emlékezést. Pedig a múlt lényege a feledés. Emlékezni tehát annyi, mint a feledést feledni. Csak a feledés örzi meg a múltat annak, ami. Az emlékezés megváltoztatja. Az időn kívülit az időbe vonja." (Bata, 1979, 231-232. о.)

${ }^{18}$ A kevés kivétel közül kiemelendő Horváth Kornélia (1999) Keleti elégiát elemző tanulmánya.

${ }^{19}$ Bata Imre $(1979,65$. o.) eme rekonstruktív szándékot a szerkezet felöl érzi megközelíthetőnek: ,[...] a [weöresi] gondolkodásmód a struktúrában adja ki magát; nem az eszme, hanem a tagoltsága, ami a belső formát kiszabja; a szerkezet tündöklik, amelyre élmény és gondolat, konkrétum és absztrakció egyaránt ráforrasztható. Ezért támadhat az a benyomásunk, hogy a tárgy - az anyag - gondolkodik itt, s nem az egyéniség." Fenti gondolatainak egy részét Weöres egy Várkonyi Nándornak írt leveléből veszi át: „Azt hiszem ezt reflexiómentes filozófiának lehetne nevezni, ahol nem a gondolatsor, hanem maga a tárgy filozofál." (Várkonyi, 1990, 116. o.) A filozófiai diskurzus és a versszöveg közötti közvetlen átjárhatóság tételezéséről tanúskodnak Rónay György észrevételei is, igaz, esztétikai szempontból elítélve azt: „A költőnek általában javára válik, ha filozófiai »képzettsége« van; a költészet ellenben kárát látja, ha egy filozófia kifejezésének szolgálatába szegődik. Weöres Sándor három utolsó kötete (Medúza, Elysium, A fogak tornáca) valóságos illusztrációja ennek a tételnek.” (Rónay, 2003, 167. o.) Vö. „A filozofáló vers és a verssé vált filozófia persze nem azonos egymással, de éppen ez utóbbinál - aminek körébe Weöres költészetének nagy része tartozik - az értelmezéshez tudni kell, hogy mi az, ami transzformálódik, átlényegül és költészetté lesz." (Kenyeres, 1983, 23. o.)

${ }^{20}$ „A spirituális cél és a megvalósítására adott materiális eszköz, a nyelv ellentéte olyan feszültséget hoz 
létre ebben a költészetben, amely egyrészt a kreatív fantázia szélsőséges megnyilvánulásait, másrészt az ember valóságos viszonyrendszerét feltáró esztétikum megszületését eredményezi." (Kabdebó, 1980, 215. o.)

${ }^{21}$ „A Fü, fa, füst kialakulása évekbe telt. Itt az alaptéma, hogy pólyáskoromban, ha az utcán tologattak a kiskocsiban, szanaszét mutogattam és gügyögtem: »fü, fa, füst«. A vers első sejtelme, természetesen, nem a pólyáskori pötyögésem, hiszen ez az emlékezetem elötti időben történt; és az sem, mikor az esetet anyám elmondta és emlékezetembe rögzítette: hanem, mikor a hallomás-élmény emléke elöször jelentkezett bennem nyomatékosan, a verssé válás igényével. Ez történt tán 18-20 éves koromban, és a verset végre is megírtam huszonnégy éves fejjel; tehát a kialakulás kb. fél évtizedig tartott; majdnem annyi ideig, mint amennyi a hallomás-élmény időpontja és a vers-csíra jelentkezése közt lefolyt." (Weöres, 2011, 95-96. o.)

${ }^{22}$ Lie-ce Kr. e. a IV. században élt, Lao-ce gondolatait fóképp metafizikai irányban fejlesztette tovább. Az általa írt Lie-ci a taoizmus második nagy alkotókorszakához tartozik.

${ }^{23}$ A kifejezés fordítása: 'Légy önmagad!'.

${ }^{24} \mathrm{Az}$ elképzelés nem áll messze a taoizmustól sem. Vö. „Nem szép az őszinte szó, / nem őszinte a szép szó. / Nem ékes-szavú a jó. / Az ékes-szavú nem jó. / A tudó nem beszél, / a nem-tudó beszél. / A bölcs nem gyüjt, / mindent az emberekért tesz / és neki is jut. / A természet út-ja / segít, nem sarcol. / A bölcs ember út-ja / használ, nem harcol.” (Lao-ce, 1994, 81. vers). Lásd még: „A tökéletes: akár a tökéletlen. / Müködése véghetetlen. / A teljesség: akár az üresség. / Müködése mérhetetlen. / Az egyenes, mint a görbe, / a szellemes, mint a döre, / az ékes szó, mint dadogó. / A mozgás a fagyot legyőzi, a nyugvás a hevet legyőzi, / a béke a rendet megörzi." (Lao-ce, 1994, 45. vers)

${ }^{25}$ Pontosabb nevén: A legmagasabb bölcsesség gyémántvágójának szútrája (Vadzsraccshedika Pradzs-nyápáramitá Szutra), http://www.freeweb.hu/ tarrdaniel/documents/Mahayana/gyemantszutra.htm

${ }^{26}$ Vö. „A jelek közt tévelygő ember azt hiszi, hogy észleletei önélettel rendelkezö, független tárgyak »híradásai«". (Gyémánt..., 1998, 32. o.)

${ }^{27}$ A dharma jelentése: 'tartani, megtartani'. , ,[...] az a szellemi alapelv vagy finom alkotó erő, amely mindennek a mélyén rejlik, mindent fenntart, mindent azzá tesz, ami." (Baktay, é. n., 16. o.)

${ }^{28}$ A hinduizmus a dharma követésének többfajta módját dharmángának ('a dharma ágazatai') nevezi, s fa képében ábrázolja (Baktay, é. n., 36. o.).

${ }^{29}$ A teljes rendszert lásd: Baktay (é. n., 36-57. o.).

${ }^{30}$ „A tarka egység $\|$ részekké szakadt, / rámzúdult a kü\|lönbség-áradat. / Képzelj faága \|kat: mindegyiken / sok két- és három \|magvú tok terem: / így lett lassacskán || mindennek neve / párjával: tej-víz, \|fe- hér-fekete, / orr-fül, huszár-ba \|ka, fésü-kefe / s hármasban: ele || fánt-zsiráf-teve, fü, fa füst.” Megjegyzendő, hogy az itt tárgyalt szabályszegő sorok majd mindegyike $6 \| 4$ osztatú 10 -esnek is felfogható. Az ütemhangsúly ekképpen való elrendezése azonban ugyanolyan következetességet mutat, mint a szöveg elöbbi leírása, azaz e tény önmagában nem cáfolja az eddigi gondolatmenet létjogosultságát.

${ }^{31} \mathrm{Az}$ epizodikus emlékezet/szemantikus emlékezet fogalompárt - M. Brownra és E. Tulvingra hivatkozva - Igor Szmirnov (1999, 113-114. o.) értelmezte újra: míg az első terminus az alany kollektívummal döntően azonos emléknyomait jelöli, addig a második a diskurzusba szervezett és interpretált emlékek önkényes, de az egyént önmaga számára is megnyilvánító sorozatát.

${ }^{32}$ A létrejövő nyelvhasználati mód a politikai diskurzust is ironikus-parodisztikus felhangokkal itatja át: ,[...] s oly fontos, mint nagy dörgeteg beszéd, / mitől országok esnek szerteszét / és véres lesz a puszta és a rét, / ha kimondom e szent varázsigét: / fü, fa, füst."

${ }^{33}$ A vers - meglehetősen áttételesen - a címet alkotó fönevek etimonjait is megmozgatja, hiszen a 'fa' történeti jelentései között szerepel az 'erdő' (vö. a mitikus emlékezetről mondottakkal). A 'fü' 'kötél', a 'füst' 'sejtés, sejtelem' szematikumot őriz. A 'fü' - ebben az interpretatív keretben - metaforikusan összekötheti az emléknyomot a konstruált emlékezettel, míg a 'füst' az emlékezet szerveződésére utalhat (Benkö, 1984, I., 822-823. o.; 998. o.; 1004-1005. o.).

${ }^{34}$ Utóbbit a jambikus lejtésbe beszürődő pirrichiusok is hangsúlyossá teszik.

${ }^{35}$ Vö. „Vitorlás / egy szó elindul / egy vitorlás szó útra kél / messze messzire / vitorlás / ha visszatér / egy szó kikötője / az emlékezetemben" (Egy fogalom kanyargásai; Weöres, 2009, III., 384. o.).

${ }^{36}$ „Korábbi kötetei kapcsán Tóth Krisztinát gyakran érte az »újholdasság« vádja, némileg jogosan persze, hogy úgynevezett »tárgyias« lírát müvel, túlságosan kiszámíthatóan, többnyire kötött dalformában.” (Jász, 2002, 1326. о.)

${ }^{37}$ Vö. „Fiatal líránkat [...] nem fojtogatta az, ami epikusainkat. Legfeljebb az elzártság, paradox módon, egyrészt légiesítette, másrészt a látható valóság felé ösztönözte. Így tágította a harmadik nemzedék, Dsida Jenő, Radnóti Miklós, Weöres Sándor, Vas István, Jékely Zoltán, Zelk Zoltán, Rónay György korosztálya a líra témakörét, az irracionális és metafizikus gondolat legmodernebb áramaitól az eddig még versbe nem foglalt vaskosig. A líra alapformáját, a vershangot Babitstól, Kosztolányitól, a nagy nemzedéktől kapták készen, sőt a teljességigény örök nyugtalanságát is." (Lengyel, 1946, 7. o.)

${ }^{38}$ Tóth (é. n.) szerint a teljes személytelenség egyrészt fikció, másrészt már meg is valósították (Weöres). Ám a túlságosan személyes megszólalást is kerülni kell - mondja. Ennek különböző technikái vannak, Takács Zsuzsa például groteszk hangvételt alkalmaz. 
Vö. ,[...] ez a kettősség, vallomásos énfeltárásnak és a mesterség személytelen játékainak az egybejátszatása [...] adja ki ennek a kötetnek [a Magas labdának] a belső életét.” (Takács, 2009, 115. o.) Lásd még: „Tóth Krisztina költészete [...] roppant személyes, noha nem vallomásos. Többnyire jelen van valamiféle eltávolító eszköz, valamiféle szürő, hol szerepjáték, hol történetek vagy történettöredékek, s ezeken keresztül mutatkozik meg az egyes szám első személy.” (Keresztesi, é. n.) Továbbá: „Az árnyékember kétarcú poétikájának kerete a szövegek személyessége, mely én-szituációkra hullik szét, de ezeket a tudatosság és a reflexivitás mégis összegyüjti egyetlen alakzatban. Olyan személyesség ez tehát, melynek mind az intimitás, mind pedig az én-szóródás okán nincs végső jelentője [...]”. (Szüts, 2001, 29. o.)

${ }^{39}$ Mivel a Weöres-poétikát eme kérdéskörök mentén másutt (Boros, 2006, 2011a, 2011b) már részletesen leírtam, itt arra csak jelzésszerü utalásokat teszek.

${ }^{40}$ „A Weöres-költészet személyiség- vagy személyességfelfogásáról jó ideje ugyanaz a néhány - köztük esetenként a költő, illetve az œuvre egyes, ebben a vonatkozásban határozottan fogalmazó darabjai által mintegy előregyártott - klisé forog közkézen a recepcióban. Az, hogy ezek meglehetösen makacsul rátapadtak az életmú értékelésére vagy feldolgozására vállalkozó kritikai nyelv szókészletére, egy ideje jóval inkább akadályt, mint lehetőséget jelent a Weöres újraértékelésére vagy irodalomtörténeti újrapozícionálására tett kísérletek számára." (Kulcsár-Szabó, 2013, 555. о.) ${ }^{41}$ Meglátásom szerint hasonló a helyzet a Rakovszky
Zsuzsa-korpusz befogadását illetően.

${ }^{42}$ „Most is ugyanazt gondolom, csak / kimondhatatlan unom a beszédet. / Unom gondolni: tegnap, holnap, / tudni, hogy ágyazódik részlet / egészbe, és hogy hullik szét naponta, / unom, hogy folyton ágyazódik, / hogy fölkelődik, pontról pontra / ugyanúgy mindig, alszik -tól -ig, / utazik -tól -ig, alszik ott is, / hajat vágat, igazít sálon, / gondol semmit, azt is magának, / metróüvegbe néz és látom, / sétál, dohányzik, ez ne volna, / fáraszt ismerni és köszönni, / csak ez a test, ne lenne dolga / annyi másik közt menni-jönni, / le kéne szokni tényleg (erröl / eszembe jutott egy barátom: / „nincs cigarettám, már leszoktam, / már csak emberek közt dohányzom”) / - nagyon unom, hogy csak emberek közt. / Kutyákkal kéne társalogni, / nézni macskát, fület hegyezni, / szagra szagokkal válaszolni - / meg se mozdulni. Minden eldől / úgyis. Eldőlni hónapokra. / Hallgatni, hagyni nőni bentröl / a csöndet, nézni, hogy befonja / süket mosolyom szépen a lián. / Nem jutna át, csak néha, kúszva rajta / egy-két ravasz / szóindián." (Szóindián; Tóth, 1997, 44-45. o.) Ennek ellenére a recepcióban túlhangsúlyozottnak tünik a nyelvkritikai attitüd tételezése. Szüts Terézia (2001, 25-27. o.) például a nietzschei és a de Man-féle retorika mentén jelöli ki a költő textusainak megközelíthetőségét, Nagy Boglárka (2007, 46-56. o.) a jelentés elbizonytalanításáról, Keresztury Tibor $(2002,250-251$. o.) nyelvvesztésröl, a sza- vak érvénytelenné válásáról, Csobánka Zsuzsa (é. n.) a szavak kimondhatóságába vetett hit megrendüléséről értekezik. Ritka kivételként említendő Halmai Tamás (2008, 100-106. o.) Bárka-elemzése: „Miután címként a verset magát nevezi meg, a szöveg öndefiníciójaként is fölfogható [mármint a bárka]: ebben az összefüggésben a vers és általában a nyelv mint alkalmat nyújtó, a túlélést biztosító közeg értékelődik fel."

43 „A kötet sok darabjában az imént említetteknél sokkal közvetlenebb alkotó átsajátításokkal érvényesül a »minden idézet« elv és felismerés [...]. [...] Ars poetica és nyelvfilozófia itt összefonódik [...], s tán elcsodálkozunk, hogy eddig az alkotás- és megismerés-folyamatnak, az ars poeticának ez a lényegi problémaköre nem kapott (vagy legalábbis nem ekkora) figyelmet a költőtől.” (Juhász, 2010, 54. o.) Vö. „[...] Tóth Krisztina lírája tradicionális líra, amely egyfelől vállalja a saját hagyománnyal járó pátoszt, másfelől viszont önnön tradíciójához már csak nosztalgiával tud viszonyulni." (Juhász, 1995, 482. o.)

${ }^{44}$ Vö. még: „Az ilyen készen kapott szókapcsolatok, sorok aztán beágyazódnak a készülő szövegbe, vagy vándorolni kezdenek és esetleg éveken át keresik a helyüket. Az, hogy a költő adott pillanatban mit körít köréjük, vagyis mibe ágyazódnak be, nagy mértékben függ az adott irodalmi kontextustól [...]”. (Tóth, é. n., 4. o.)

45 „Ma a költők egy része menekül a hagyománytól. (Talán azért, mert a kritika minden esetben azt keresi, ki kihez tartozik, ki kinek az örököse.) Holott szükségszerü, hogy a hagyományra épüljön minden, amint a fa csak a talajból nőhet ki. Maga a nyelvi anyag is hagyományos, amit használunk. Tehát senki sem tud kilépni a hagyományból, bármennyire is törekszik erre." (Visszaadni..., 1993, 132. o.)

${ }^{46}$ Vö. a Hála-változattal, amelynek pretextusai: Weöres Sándor, Hála-áldozat; Gergely Ágnes, Hálaadás-parafrázis című szövege. „Arany színekben izzó szén szavak. / Babits a fény, Ady a nagy zsarátnok. / Boldog-szomorú lidérc leng: ha játsztok, / zümmögi halkan, csak tüzzel szabad, // Nemes Nagy dolgot! Hány láng sisteregne, / Füst csapna fel, Weöres sziporkatánc, / Kormos Vas bongna, izzana a rács, / mennyi kanyargó seb, mi nem heged be, // s bár igaz lenne majd, hogy lesz vigasz - / J. A. szájából érdes volt az élet, / Petri szájából szép volt a pimasz: // bárhogy mozduljak, lángnyelven beszélek, / torkomban hangjukkal, de semmi az, / ha tölük éghet éneke az énnek." (Hála-változat; Tóth, 2009, 14. o.)

${ }^{47}$ Vö. „Még általános iskolás koromban halottam egyszer a rádióban $A$ walesi bárdokat, s teljesen lenyügözött a vers. Egészen mélyen megérintett, bár a szövegéböl egy szót sem értettem. [...] Úgy éreztem, a balladák legbelső lényegemre hatnak. Mostanában kisfiamnak, Marcinak olvastam rengeteget, neki is elképesztően tetszettek. Egyik kedvence a Zách Klára [...]. A történet, a levágott ujjak és hasonlók abszolút nem érdeklik, valami sokkal ösibbet, a költészet dallamát hallja ki belőle." (Lackfi, 2003, 82-83. o.) 
${ }^{48}$ „Aki látott már költőt munkában, az pontosan tudja, hogy ez a legkevésbé sem hasonlít a romantikus képhez, az ihlet nem jön, a vers nem szólal meg egyszerre. A költőnek van egy-két használható szava, szerencsés esetben egy-két talált sora, és ezek alapján próbálja meg rekonstruálni a vers egészét. Azért mondom ilyen bátran, hogy a vers egészét, mert saját tapasztalatom szerint a szerzőnek mindig van valami előzetes elképzelése a még meg nem született szövegtest terjedelméről, hangzásáról, hangulatáról: mintha egy már eleve kész képződményt próbálna kiásni saját tudata rétege alól, és a meglévő szavak, töredékek ennek felszínre került, megtalált darabkái volnának. Ez a kiásás kívülről nézve nagyon szánalmasan fest. A fejben intenzíven dolgozó költő mozdulatlanul ül, semmit nem ír le. Időnként feláll, kávét iszik, jön-megy, indokolatlanul sokszor lefekszik. Mi baja van, fáj valamije?” (Tóth, é. n.,, 1-2. o.) „Rakovszky Zsuzsa írja, hogy fontos megtervezni, mi kerüljön egy versbe, de ha csak az kerül bele, amit elterveztünk, az kevés. A szöveg írás közben egyszercsak beindul, magával ragad, és elöre nem sejtett elemek kerülnek bele." (Lackfi, 2003, 95. o.)

${ }^{49}$ „Nem is oly rég egy kritikában valaki üdvözölte hajlandóságomat, hogy végre lemondjak a kötött formákról. Mintha ez valami kívánatos és elvárható fejlődési fokozat lenne, amelynek túlsó, ideális végén a forma bábjából végre kiszabadulhat a szerzői szándék. A forma nem báb, a forma maga a vers, legyen kötött vagy szabad.” (Tóth, é. n.,, 21. o.) Jász Attila (2002, 1325. o.) szerint ,a kesernyés hang és a látszólag könnyed, felszínes (álomszerüséget) imitáló forma [...] igen jól áll Tóth Krisztinának.” Lásd még: „Az érzelem újra [...] belépőt kap a versbe. [...] Az érzelem anyag. Formálni kell. Munkálni kell rajta, különben elkerülhetetlenül érzelmességbe fullad. Az érzelmek ellen elkerülhetetlenül be kell vetni a kötött formát. [...] Gátat kell szabni neki, hogy tagolatlan mozgását a jambus ritmusához igazítsa, hogy ne szaladjon túl a sorvégeken. Oda például szögesdrót gyanánt rímpárokat jó kifeszíteni." (Vörös, 1994, 117-118. o.)

${ }^{50} \mathrm{~V}$ ö. „De ahogy haladunk előre, megszólal a kötetben egy másik hang is, amely szöges ellentéte [...] az egzisztenciális töltetü sebzett személyességnek. A másik véglet ez: a költő mint rím- és szójátékok pirotechnikusa, mások verseinek át- és újraírója, önnön mesterségbeli bravúrjaira két kézzel mutogató mutatványos. [...] (Az ilyesminek egyébként az egzisztenciális tétje is jótékonyan csekély: lelkileg és költőileg odaveszni nemigen lehet tőle.)" (Takács, 2009, 114. o.)

${ }^{51}$ „Olyan, hogy szélverem, ugye, nincsen.” (Tóth, é. n., 23. о.)

${ }^{52}$ „A versekben persze részben tapasztalt, részben képzelt terek jelennek meg, a kettőből gyúrom össze a verset. A vers valósága amúgy is egészen máshol van. Jóval később évekig visszatérő, nagyon fura álmom volt az a szoba, ahol Párizsban lakom. Aztán hiába kerültem tényleg Párizsba, és laktam egy tel- jes évig egy padlásszobában: amikor később hazajöttem, mégsem a valós lakásba álmodtam magam, hanem mindig abba, amelyet korábban álmomban olyan jól elképzeltem. Az álmodott lakás közege maradandóbbnak bizonyult a valódiénál. Így van ez valahogy a verssel is, az ember elképzelt, belső lakásába behordja tapasztalatait, élményeit, de amit mindebből létrehoz, az már nem egy létező lakás. Ezt tekinthetjük akár egyfajta párhuzamos valóságnak is, hiszen sokszor valódibb a valónál." (Lackfi, 2003, 80-81. o.)

${ }^{53}$ Nagy Boglárka $(2007,49$. o.) időben visszafelé is mutató 2007-es megjegyzése szerint: „A látványból eredő felidézéstechnika ezúttal is gyakori verselem, de a kötetből epizodikusan kirajzolódó történet(ek), illetve a megélt történet(ek)re való emlékezés aktusa [...] többször lesz indító mozzanata az egyes költeményeknek."

${ }^{54}$ Vö. „A Magas labda a felszámolás kötete. Mintha egy kései líra alapkövezete lenne, mélyfúrások ahhoz a bizonyos leütéshez, egyérintőzés. A tét óriási, és emiatt kimondhatatlanok lesznek a dolgok nevei, aztán belátja, felesleges nevekben vagy kimondhatóságban bízni, amikor a mondatokban, szavakban sem lehet. Az emlékek előhívóként működnek, kétesélyes, kiég-e majd a kép, és még mindig nem a szövegeket méltatom." (Csobánka, é. n.)

${ }^{55}$ „Az egyik ilyen sajátosságot már említettem: a Havak éve ciklusban Tóth Krisztina a hangsúlyt a mondatról a verssorra teszi. Ez is áthelyezés: a kijelentésről (ami egy grammatikusan megformált mondat) az írásra, a vizuálisan megragadható szövegre való áttétel (a kijelentés fontossága csökken ezzel a gesztussal, annak viszont, hogy az írás versként létezik, nö)."

${ }^{56}$ Vö. a 61. lábjegyzetben írtakkal!

${ }^{57}$ Például: ,Az orchidea nem veszíti el illatát, csak mert senki sem szagolja, a csónak nem süllyed el, csak mert senki sem ül benne. A bölcs nem hagyja el az Utat, csak mert senki sem ismeri azt. A Természet által van ez így.” (Wen-Ce, 1995, 60. o.)

${ }^{58}$ Például a Tao Te King 16. versében: ,juss el a végső ürességig / állhatatosan örizd a csendet / a tízezer dolog mind együtt föláll [...]" = http://terebess.hu/ keletkultinfo/karatson.html\#Kap16

${ }^{59}$ Weöresnek mindkettőben bőven volt része.

${ }^{60}$ „A szöveg harmadik funkciója az emlékezet. A szöveg nemcsak új jelentések generátora, hanem a kulturális emlékezet kondenzátora is: emlékeztetni tud saját korábbi kontextusaira. [...] Ha a szöveget pusztán önmagában érzékelné a befogadó, akkor a múltat összefüggéstelen részletek mozaikjának látnánk. A befogadó számára azonban a szöveg - mindig valamely jelentésegész metonímiája, egy nem diszkrét lényeg diszkrét jele. Az adott szöveg értelemegészéhez hozzájáruló kontextusok összessége, azok a szövegek tehát, amelyek meghatározott módon mintegy inkorporálódnak az aktuális szövegbe - mindez 
együtt nevezhető a szöveg emlékezetének." (Lotman, 2002, 32-33. o.)

${ }^{61}$ Vö. „Azt hiszem, lassan lelepleződik a tervem, hogy a fenti gondolatmenettel a következö tételmondatig jussak el: az áthelyezések sora, köztük kint és bent áthelyezése szintén áthelyezése (metaforája) valaminek; annak, hogy a személyes idő végpontját jelentő halál elől menekülni próbáló »én« személyes történetét - könyvként, sőt versként - Mnémoszüné elé tegye le: változtathatatlan formában, úgy, ahogy az istennő számára látható - mint önéletrajzot." (Prágai, 2002, 121. o.)

${ }^{62}$ Ezért nehéz Margócsy Istvánnal (2003, 178. o.) egyetérteni, aki a Tóth Krisztina-i hagyományfelfogást messzemenően relativizáltnak nevezi.

${ }^{63}$ Vö. „A versek az idő múlása ellenében fogantak, hiszen a mulandósággal szemben érzett mély egzisz- tenciális szorongás hatja át őket [...], miközben legfőbb poétikai törekvésük szerint a költészet, mely maga az emlékezet - prousti vagy celani módra ellenszegül a múló időnek." (Szávai, 2009, 136. o.)

${ }^{64}$ Efféle tudatosan létrehozott hagyománysort ír le a szerző is, amikor saját versét (Program) Orbán Ottó Hallod-e, te sötét árnyék címủ költeményére, azt pedig egy csángó népdalra (Hallod-e, te szelídecske...) vezeti vissza (Tóth, 2002, 7-9. o.). Mindezen túl a gyüjteményes kötet időrendjének megfordítása, azaz a keletkezett versek jelenből múlt felé tartó elrendezése explicit példája a konstruált (ön)szövegemlékezetnek.

${ }^{65}$ Vö. a negyedik szakaszt az Ének a határtalanról felütésével. 